\title{
Pengaruh Habits of Mind dan Kemandirian Belajar Siswa terhadap Kemampuan Berpikir Reflektif Matematis
}

\author{
Condro Endang Werdiningsih ${ }^{1 *}$, \& Linda Khoerunisa ${ }^{2}$ \\ ${ }^{1,2}$ Universitas Indraprasta PGRI, Jakarta, Indonesia
}

\begin{tabular}{l} 
INFO ARTICLES \\
Article History: \\
Received: 18-06-2021 \\
Revised: 20-12-2021 \\
Approved: 21-12-2021 \\
Publish Online: 31-12-2021 \\
\hline Key Words: \\
Habits of Mind; Self-Regulated \\
Learning; Reflective Thinking \\
Ability;
\end{tabular}
Ability;

\begin{abstract}
This research has the purpose of knowing: (1) the influence of habits of mind and students self-regulated learning together on mathematical reflective thinking ability; (2) the influence of habits of mind on mathematical reflective thinking ability; and (3) the influence of students self-regulated learning on mathematical reflective thinking ability. The research method used is the survey method. Correlation with double regression analysis techniques. The target population in this study is all students at MTs Tahdzibun Nufus, West Jakarta. The results concluded that: (1) there was a significant positive influence on students' learning habits and self-regulated learning together on mathematical reflective thinking skills; (2) there is a positive and insignificant influence on mathematical reflective thinking; (3) there is a positive and significant influence between self-regulated learning on mathematical reflective thinking.
\end{abstract}

\begin{abstract}
Abstrak: Penelitian ini memiliki tujuan untuk mengetahui: (1) pengaruh habits of mind dan kemandirian belajar siswa secara bersama-sama terhadap kemampuan berpikir reflektif matematis; (2) pengaruh habits of mind terhadap kemampuan berpikir reflektif matematis; dan (3) pengaruh kemandirian belajar siswa terhadap kemampuan berpikir reflektif matematis. Metode penelitian yang digunakan adalah metode survei. Korelasi dengan teknik analisis regresi ganda. Populasi target dalam penelitian ini adalah seluruh siswa di MTs Tahdzibun Nufus Kota Jakarta Barat. Hasil penelitian menyimpulkan bahwa: (1) terdapat pengaruh positif yang signifikan habits of mind dan kemandirian belajar siswa secara bersama-sama terhadap kemampuan berpikir reflektif matemati; (2) terdapat pengaruh positif dan tidak signifikan habits of mind terhadap kemampuan berpikir reflektif; (3) terdapat pengaruh positif dan signifikan antara kemandirian belajar terhadap kemampuan berpikir reflektif matematis.
\end{abstract}

Correspondence Address: Jl. Raya Tengah No.80, RT.1/RW.3, Gedong, Kec. Pasar Rebo, Kota Jakarta Timur, DKI Jakarta, Indonesia, Kode Pos 13760; e-mail: endangcondro4@gmail.com

How to Cite (APA 6 $^{\text {th }}$ Style): Werdiningsih, C.E., \& Khoerunisa, L. (2021). Pengaruh Habits of Mind dan Kemandirian Belajar Siswa terhadap Kemampuan Berpikir Reflektif Matematis. JKPM (Jurnal Kajian Pendidikan Matematika), 7(1): 85-94. http://dx.doi.org/10.30998/jkpm.v7i1.9942

Copyright: 2021 Condro Endang Werdiningsih, Linda Khoerunisa

Competing Interests Disclosures: The authors declare that they have no significant competing financial, professional or personal interests that might have influenced the performance or presentation of the work described in this manuscript. 


\section{PENDAHULUAN}

Pendidikan merupakan hak setiap manusia. Seseorang melalui pendidikan mendapatkan pengetahuan, ilmu, dan pengalaman. Oleh karena itu, salah satu faktor penting sebagai penentu mutu sumber daya manusia adalah pendidikan. Menurut Krissandi, \& Setiawan (2018) yang menyatakan bahwa pendidikan pada hakikatnya merupakan suatu upaya sadar untuk menyiapkan sumber daya manusia dalam mengembangkan potensi untuk menghadapi kehidupan di masa sekarang maupun masa depan. Seorang yang berpendidikan tentu akan lebih memiliki potensi lebih dalam memajukan negaranya.

Di Indonesia, rendahnya pendidikan masih menjadi salah satu permasalahan yang dihadapi saat ini. Salah satu faktor yang menyebabkan beberapa masalah yang tejadi dalam pendidikan di Indonesia yaitu rendahnya nilai UN (Ujian Nasional). Walaupun UN bukan lagi menjadi penentu kelulusan siswa. Persoalan lain, rendahnya nilai rapor siswa, sulitnya siswa memahami berbagai mata pelajaran di sekolah, di mana kurikulum yang dibuat pemerintah selalu berubah-ubah, sistem sekolah yang tidak sama, cara mengajar dan pendidikan guru, kemampuan siswa dalam memahami pelajaran, orang tua siswa, dan masalah pendidikan yang berhubungan dengan masyarakat. Beberapa hal tersebut telah diungkapkan Prastowo (2014) dalam penelitiannya. Akibatnya tentu saja membuat guru dan siswa terkena dampak yang kurang baik.

Matematika merupakan pelajaran yang sulit bagi siswa. Padahal matematika merupakan salah satu pelajaran terpenting untuk menguasai pelajaran lain. Kesulitan siswa dalam mempelajari matematika diungkapkan Utarni, \& Mulyatna (2020) diantaranya karena lebih banyak berisi angka-angka dan rumusrumus. Selain itu, angka-angka pada matematika ini merupakan angka-angka yang abstrak. Hal ini menjadikan siswa perlu memahami dengan baik dalam belajar matematika. Sulitnya mempelajari matematika tidak hanya karena matematika itu sendiri melainkan dari faktor luar juga.

Berdasarkan data hasil UN tahun 2016-2018 di sekolah MTs Tahdzibun Nufus Jakarta Barat, diketahui bahwa mata pelajaran matematika dari tahun ke tahun mengalami penurunan nilai. Hal tersebut membuktikan bahwa salah satu mata pelajaran yang sulit bagi siswa adalah matematika. Salah satu organisasi pendidikan matematika internasional melalui National Council of Teacher of Mathematics (NCTM) dikutip dari Harahap, et. al. (2012) menyatakan bahwa ada beberapa aspek yang termasuk dalam kemampuan berpikir matematis di antaranya adalah kemampuan pemahaman, pemecahan masalah matematis, komunikasi matematis, penalaran dan pembuktian matematis, koneksi matematis dan representasi matematis.

Siswa sulit untuk memasukkan materi pelajaran matematika ke dalam bukti di kehidupan sehari-hari sehingga sulit bagi siswa untuk memahami matematika. Dua faktor yang mempengaruhi kesulitan memahami matematika, yaitu faktor instrinstik dan faktor ekstrinsik. Di mana faktor instrinsik meliputi minat, bakat, $I Q, E Q$, kemandirian belajar, kreativitas, efikasi, konsep, habits of mind, dan factor lain. Sedangkan faktor ekstrinsik meliputi metode mengajar, model pembelajaran, cara mengajar guru, lingkungan, dan faktor yang lainnya.

Habits of mind sangat menentukan bagaimana seorang siswa dalam menyelesaikan suatu persoalan matematika. Menurut Handayani (2015) kebiasaan berpikir matematis (mathematical habits of mind) merupakan salah satu budaya yang penting untuk dikembangkan dalam lingkungan kelas ketika siswa mempelajari matematika. Sehingga habits of mind sangat diperlukan dalam penyelesaian masalah matematika. Dengan kata lain, kebiasaan berpikir, termasuk kebiasaan berpikir matematis mampu menjadikan seseorang pelajar yang unggul. Penerapan habits of mind dalam belajar matematika yaitu siswa dapat mengamati pola, melakukan eksperimen, mendeskripsikan, menjadi pemikir, menjadi penemu, dapat memvisualisasikan, membuat dugaan, dan menebak.

Siswa dalam proses belajar membutuhkan kemandirian belajar. Bersumber dari Sudjatmiko (2019), seperti yang pernah diungkapkan Mantan Mendikbud Muhajir Effendy saat penutupan FLS2N di Tangerang, 
Para siswa harus tahu pentingnya memiliki karakter kemandirian. Dalam proses pembelajaran siswa, kemandirian adalah hal yang sangat penting. Kemandirian belajar dapat dilihat dari tingkah laku siswa saat proses kegiatan belajar mengajar sedang berlangsung. Siswa yang memiliki kemandirian belajar tentunya akan siap menerima materi yang diajarkan guru. Siswa yang tidak memiliki kemandirian belajar cenderung sering menemukan beberapa kendala atau kesulitan saat menerima materi ajar. Kebiasaan siswa yang mandiri dalam belajar tentu membantu guru untuk mencapai tujuan pembelajaran. Dengan demikian kemampuan berpikir matematis harus dilatih agar dimiliki oleh siswa.

Kemampuan berpikir setiap siswa tentunya berbeda-beda. Tinjauan penelitian Mulyatna, et. al. (2021), dalam hal pembelajaran matematika, diperlukan tingkat kemampuan berpikir yang tinggi. Berpikir reflektif menjadi salah satu hal yang diperlukan dalam mengerjakan soal matematika. Ghifari, et. al., (2021) juga memberikan gambaran pentingnya kemampuan berpikir reflektif, bahwa kemampuan tersebut memberi siswa kesempatan dalam menentukan keputusan dengan sadar dan logis bahkan pada masalah kompleks yang dihadapi. Menurut Nindiasari, et. al. (2016) kemampuan berpikir reflektif matematis menjadi dasar bagi kemampuan berpikir kritis matematika dan kemampuan metematika lainnya. Awalia, et. al. (2019) menuturkan, dalam mempelajari matematika, siswa diharapkan mengerti tentang apa yang telah dipelajari. Sejalan dengan penyampaian Edo (2018), siswa tidak seharusnya hanya diminta untuk dapat menghafal rumus-rumus matematika. Siswa harus memahami konsep-konsep matematika yang dipelajari serta menggunakan konsep-konsep tersebut secara tepat ketika ia harus mencari jawaban dari soal matematika. Karena dalam mencari jawaban dari soal matematika diperlukan ketelitian, kecermatan, kreatifitas, original, serta kritis. Menggunakan acuan Muntazhimah (2019), cakupan kemampuan berfikir reflektif matematis meliputi kemampuan untuk reacting (berpikir untuk aksi), kemampuan untuk comparing (berpikir untuk evaluasi) dan kemampuan untuk contemplanting (berpikir untuk inkuiri kritis). Berdasarkan beberapa penjelasan di atas maka peneliti tertarik untuk melakukan penelitian dengan judul "Pengaruh habits of mind dan kemandirian belajar siswa terhadap kemampuan berpikir reflektif matematis".

\section{METODE}

Metode penelitian yang digunakan dalam penelitian ini adalah metode survey dengan teknik analisis korelasional dan regresi ganda, yaitu mencari hubungan dan pengaruh antara dua variabel bebas dengan satu variabel terikat (multivariat). Variabel-variabel yang diteliti yaitu habits of mind ( $\left.\mathrm{X}_{1}\right)$, kemandirian belajar $\left(\mathrm{X}_{2}\right)$ dan kemampuan berpikir reflektif matematis (Y). Desain dalam penelitian ini bisa dilihat pada Gambar 1 ..

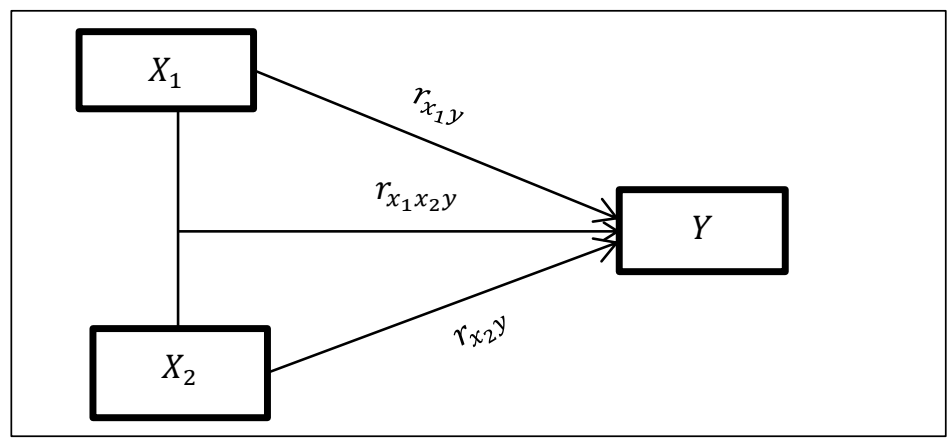

Gambar 1. Desain Penelitian

Keterangan:
$X_{1}$
: Habits of Mind
$X_{2} \quad$ : Kemandirian Belajar 


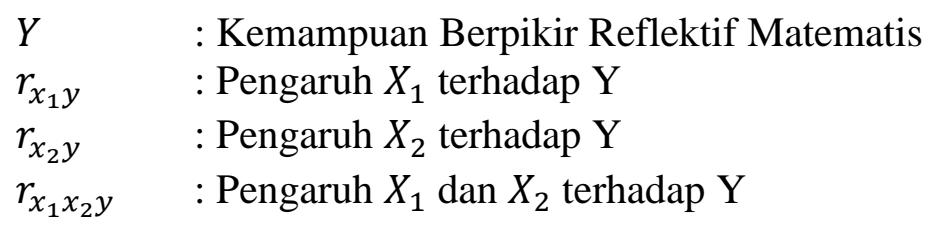

Penelitian ini dilakukan di MTs Tahdzibun Nufus Jakarta selama 5 bulan (Maret-Juli). Populasi dalam penelitian ini adalah seluruh siswa dan siswi kelas VIII semester II tahun ajaran 2019/2020 yang berjumlah 186 siswa. Adapun penelitian ini menggunakan Rumus Slovin dengan jumlah sampel 65 siswa dan pengambilan sampel yang dilakukan dalam penelitian ini menggunakan probability sampling dengan teknik simple random sampling. Pengumpulan data menggunakan angket dan soal essay yang telah divalidasi sebelumnya. Uji persyaratan analisis data yaitu dengan menggunakan Uji Normalitas untuk menguji data yang akan dianalisis normal atau tidaknya, kemudian dilakukan Uji Linearitas dan Uji Multikolinearitas. Selanjutnya pengujian hipotesis menggunakan Uji Koefisien Korelasi Ganda dan Uji Regeresi Ganda.

\section{HASIL}

Penelitian yang telah dilakukan kemudian disajikan analisis data deskriptif untuk masing-masing variable, baik itu variabel kontrol maupun variabel terikatnya. Penyajian data statistik deskriptif dari masingmasing variabel dapat dibaca dalam Tabel $1 .$.

Tabel 1. Hasil Perhitungan Data Statistik Deskriptif

\begin{tabular}{cccc}
\hline $\begin{array}{c}\text { Ukuran Data } \\
\text { Deskriptif }\end{array}$ & $\begin{array}{c}\text { Kemampuan Berpikir Reflektif } \\
\text { Matematis (Y) }\end{array}$ & Habits of Mind $\left(\mathrm{X}_{1}\right)$ & $\begin{array}{c}\text { Kemandirian } \\
\text { Belajar }\left(\mathrm{X}_{2}\right)\end{array}$ \\
\hline Mean & 64,27 & 101,5 & 98,28 \\
Median & 66,42 & 101,88 & 102,75 \\
Modus & 64,75 & 102,5 & 102,3 \\
Varians & 279,09 & 263,13 & 272,84 \\
Standar Deviasi & 16,71 & 16,22 & 16,52 \\
\hline
\end{tabular}

Sumber: diolah dari data penelitian, 2020

Berdasarkan Tabel 1., diketahui bahwa kemampuan berpikir reflektif matematis memiliki mean 64,27 dan median 66,42. Sedangkan mean untuk habits of mind adalah 101,5 dengan median 101,88. Sementara itu kemandirian belajar, memiliki mean sebesar 98,28 dan median 102,75.

Data awal yang sudah diperoleh kemudian dilakukan uji persyaratan analisis data. Uji persyaratan analisis data dalam penelitian ini meliputi: uji normalitas, uji linearitas, dan uji kolinearitas/multikolinearitas. Uji persyaratan analisis data yang dilakukan pertama adalah uji normalitas. Data terkait uji normalitas tersaji dalam Tabel 2.. Dalam uji normalitas didasarkan pada kriteria pengujian: $\chi_{\text {hitung }}^{2}<\chi_{\text {tabel }}^{2}$ terima $\mathrm{H}_{0}$

$\chi_{\text {hitung }}^{2}>\chi^{2}$ tabel tolak $\mathrm{H}_{1}$

Tabel 2. Hasil Perhitungan Uji Normalitas

\begin{tabular}{cccc}
\hline Ukuran Uji & Kemampuan Berpikir & Habits of Mind & Kemandirian \\
Normalitas & Reflektif Matematis (Y) & $\left(\mathrm{X}_{1}\right)$ & Belajar $\left(\mathrm{X}_{2}\right)$ \\
\hline$\chi^{2}$ hitung & 3,579 & 4,243 & 4,099 \\
$\alpha$ & 0,05 & 0,05 & 0,05 \\
$\chi_{\text {tabel }}^{2}$ & 12,592 & 12,592 & 12,592 \\
\hline
\end{tabular}

Sumber: diolah dari data penelitian, 2020 
Berdasarkan data Tabel 2. diketahui bahwa nilai $\chi^{2}$ hitung $<\chi^{2}$ tabel maka $\mathrm{H}_{0}$ diterima, maka data berdistribusi normal. Keberadaan data yang berdistribusi normal kemudian pada tahap uji persyaratan analisis data dilanjutkan dengan uji linearitas. Dalam uji linearitas sendiri menggunakan acuan kriteria pengujian

Terima $\mathrm{H}_{0}$ jika $\mathrm{F}_{\text {hitung }}<\mathrm{F}_{\text {tabel }}$, maka regresi berpola linier

Tolak $\mathrm{H}_{0}$ jika $\mathrm{F}_{\text {hitung }}>\mathrm{F}_{\text {tabel}}$, maka regresi tidak berpola linier

Uji linearitas dalam penelitian ini berarti uji linearitas kemampuan berpikir reflektif matematis atas habits of mind dan juga uji linearitas kemampuan berpikir reflektif matematis atas kemandirian belajar. Data terkait kedua uji linearitas tersebut tersaji dalam Tabel 3.dan Tabel 4..

Tabel 3. Tabel Penolong ANAVA untuk Uji Linearitas Regresi Kemampuan Berpikir Reflektif Matematis atas Habits of Mind

\begin{tabular}{cccccc}
\hline Sumber Varian (SV) & dk & JK & RJK & $F_{\text {hitung }}$ & F tabel \\
\hline Total & 65 & 280335 & & & \\
Regresi (a) & 1 & 263304,14 & 263304,14 & & \\
Regresi (a) & 1 & 2204,67 & 2204,67 & 0,62 & 1,87 \\
Residu & 63 & 14826,19 & 86,85 & & \\
Tuna Cocok & 38 & 7179,02 & 188,92 & & \\
Kesalahan (error) & 25 & 7647,27 & 305,89 & & \\
\hline
\end{tabular}

Sumber: diolah dari data penelitian, 2020

Tabel 4. Tabel Penolong ANAVA untuk Uji Linearitas Regresi Kemampuan Berpikir Reflektif Matematis Atas Kemandirian Belajar

\begin{tabular}{cccccc}
\hline Sumber Varian $(\mathrm{SV})$ & Dk & JK & RJK & F $_{\text {hitung }}$ & F tabel \\
\hline Total & 65 & 280335 & & & \\
Regresi (a) & 1 & 263304,14 & 263304,14 & & \\
Regresi (a) & 1 & 4755,43 & 4755,43 & 1,50 & 1,91 \\
Residu & 63 & 12275,44 & 140,79 & & \\
Tuna Cocok & 40 & 8869,85 & 221,75 & & \\
Kesalahan (error) & 23 & 340,58 & 148,07 & & \\
\hline
\end{tabular}

Sumber: diolah dari data penelitian, 2020

Dalam Tabel 3. dan Tabel 4.. baik itu uji linearitas kemampuan berpikir reflektif matematis atas habits of mind ataupun uji linearitas kemampuan berpikir reflektif matematis atas kemandirian belajar samasama menghasilkan hubungan $F_{\text {hitung }}<F_{\text {tabel }}$. Artinya bahwa hubungan $F_{\text {hitung }}<F_{\text {tabel }}$ berdasarkan acuan kriteria pengujian $\mathrm{H}_{0}$. Dengan diterimanya $\mathrm{H}_{0}$, kemampuan berpikir reflektif matematis atas habits of mind dan juga uji linearitas kemampuan berpikir reflektif matematis atas kemandirian belajar, regresinya berpola linear.

Uji persyaratan analisis data terakhir yang dilakukan sebelum pada pengujian hipotesis adalah uji kolinearitas/multikolinearitas. Kriteria uji multikolinieritas, jika VIF > 10 atau Tolerance menjauhi angka 1, maka terdapat masalah multikolinieritas. Jika VIF $<10$ atau Tolerance mendekati angka 1, maka tidak terdapat masalah multikolinieritas Dari perhitungan diperoleh nilai VIF $=1,46<10$ dan nilai Tolerance $=$ $0,68>0,1$; sehingga disimpulkan antara $X_{1}$ dan $X_{2}$ dalam model regresi tidak terdapat kolinearitas/ multikolinearitas. 
Ketiga uji persyaratan analisis data, yaitu: uji normalitas, uji linearitas, dan uji kolinearitas/multikolinearitas dapat dipenuhi semua syaratnya, maka dapat dilanjutkan dengan pengujian hipotesis.

Pengujian hipotesis pertama yang dilakukan adalah uji korelasi ganda. Uji korelasi ganda ini dimaksudkan untuk mengetahui ada tidaknya korelasi (hubungan) antara habist of mind ( $\mathrm{X}_{1}$ ) dengan kemampuan berpikir reflektif matematis $(\mathrm{Y})$, antara kemandirian belajar $\left(\mathrm{X}_{1}\right)$ dengan kemampuan berpikir reflektif matematis $(\mathrm{Y})$, serta antara habits of mind $\left(\mathrm{X}_{1}\right)$ dan kemandirian belajar siswa $\left(\mathrm{X}_{2}\right)$ secara bersamasama dengan kemampuan berpikir reflektif matematis (Y).

Korelasi $\mathrm{Y}$ atas $\mathrm{X}_{1}$ diperoleh nilai $\mathrm{t}_{\text {tabel }}$ pada $\alpha=0,05 \mathrm{dan} \mathrm{dk}=\mathrm{n}-2=63$ untuk uji dua pihak $\mathrm{t}_{\text {tabel }}$ adalah 1,99. Karena $t_{\text {hitung }}>\mathrm{t}_{\text {tabel }}$ yaitu 3,06 $>1,99$ maka pengujian hipotesis menerima $\mathrm{H}_{1}$ dan menolak $\mathrm{H}_{0}$, dengan demikian disimpulkan terdapat korelasi (hubungan) yang signifikan antara habist of mind $\left(\mathrm{X}_{1}\right)$ dengan kemampuan berpikir reflektif matematis (Y).

Sedangkan untuk korelasi $\mathrm{Y}$ atas $\mathrm{X}_{2}$ diperoleh nilai $\mathrm{t}_{\text {tabel }}$ pada $\alpha=0,05 \mathrm{dan} \mathrm{dk}=\mathrm{n}-2=63$ untuk uji dua pihak $\mathrm{t}_{\text {tabel }}$ adalah 1,99. Karena $\mathrm{t}_{\text {hitung }}>\mathrm{t}_{\text {tabel }}$ yaitu 4,94 $>1,99$ maka pengujian hipotesis menerima $\mathrm{H}_{1}$ dan menolak $\mathrm{H}_{0}$, dengan demikian disimpulkan terdapat korelasi (hubungan) yang signifikan.

Terakhir adalah korelasi $\mathrm{Y}$ atas $\mathrm{X}_{1}$ dan $\mathrm{X}_{2}$. Pada pengujian korelasi ini, nilai yang diperoleh menggunakan $\mathrm{F}_{\text {tabel }}$ pada taraf signifikan 0,05 dengan $\mathrm{dk}_{\text {pembilang }}=2$ dan $\mathrm{dk}_{\text {penyebut }}=\mathrm{n}-\mathrm{k}-1=62$ adalah 3,14. Koefisien korelasi secara bersama-sama antara habits of mind $\left(\mathrm{X}_{1}\right)$ dan kemandirian belajar $\left(\mathrm{X}_{2}\right)$ dengan kemampuan berpikir reflektif matematis (Y) sebesar 0,54 tergolong cukup. Keberadaan skor kemampuan berpikir reflektif matematis dapat dijelaskan oleh variabel habits of mind $\left(\mathrm{X}_{1}\right)$ dan kemandirian belajar $\left(\mathrm{X}_{2}\right)$ sebesar $29,16 \%$, sedangkan sisanya sebesar 70,84\% ditentukan oleh faktor (variabel) lain. Tingkat keberartian koefisien korelasi ganda diuji dengan uji $\mathrm{F}$, dan diperoleh $\mathrm{F}_{\text {hitung }}=12,79>\mathrm{F}_{\text {tabel }}=3,12$ pada taraf signifikan 0,05 , sehingga disimpulkan bahwa terdapat korelasi (hubungan) yang signifikan antara habits of mind $\left(\mathrm{X}_{1}\right)$ dan kemandirian belajar siswa $\left(\mathrm{X}_{2}\right)$ secara bersama-sama dengan kemampuan berpikir reflektif matematis (Y).

Berdasarkan uji korelasi ganda diperoleh hasil adanya korelasi (hubungan) antara habist of mind $\left(\mathrm{X}_{1}\right)$ dengan kemampuan berpikir reflektif matematis $(\mathrm{Y})$, antara kemandirian belajar $\left(\mathrm{X}_{1}\right)$ dengan kemampuan berpikir reflektif matematis $(\mathrm{Y})$, dan juga antara habits of mind $\left(\mathrm{X}_{1}\right)$ dan kemandirian belajar siswa $\left(\mathrm{X}_{2}\right)$ secara bersama-sama dengan kemampuan berpikir reflektif matematis (Y). Selanjutnya, untuk mengetahui bagaimana pengaruhnya, dilakukan uji analisis regresi ganda. Uji analisis regresi ganda ini secara terperinci untuk mengetahui bagaimana pengaruhnya habits of mind $\left(\mathrm{X}_{1}\right)$ dan kemandirian belajar siswa $\left(\mathrm{X}_{2}\right)$ secara bersama-sama terhadap kemampuan berpikir reflektif matematis (Y), bagaimana pengaruhnya habits of mind $\left(\mathrm{X}_{1}\right)$ terhadap kemampuan berpikir reflektif matematis $(\mathrm{Y})$, serta bagaimana pengaruhnya kemandirian belajar siswa $\left(\mathrm{X}_{2}\right)$ terhadap kemampuan berpikir reflektif matematis $(\mathrm{Y})$.

Sehingga uji analisis regresi ganda $\mathrm{Y}$ atas $\mathrm{X}_{1}$ dan $\mathrm{X}_{2}$, untuk kriteria pengujiannya,

$\mathrm{H}_{0}$ : regresi ganda $\mathrm{Y}$ atas $\mathrm{X}_{1}$ dan $\mathrm{X}_{2}$ tidak signifikan

$\mathrm{H}_{1}$ : regresi ganda $\mathrm{Y}$ atas $\mathrm{X}_{1}$ dan $\mathrm{X}_{2}$ signifikan

Hipotesis tersebut diuji menggunakan uji $\mathrm{F}$ dengan kriteria pengujian: terima $\mathrm{H}_{0}$ jika $\mathrm{F}_{\text {hitung }}<\mathrm{F}_{\text {tabel}}$, dan tolak $\mathrm{H}_{0}$ jika $\mathrm{F}_{\text {hitung }}>\mathrm{F}_{\text {tabel }} . \mathrm{F}_{\text {tabel }}$ ditentukan dari tabel distribusi $\mathrm{F}$ untuk $\alpha$ tertentu $($ misal $\alpha=0,05)$ serta $d k_{\text {pembilang }}=2$ dan $d k_{\text {penyebut }}=62, \mathrm{~F}_{\text {tabel }}=3,14$, ternyata $\mathrm{F}_{\text {hitung }}>\mathrm{F}_{\text {tabel }}$ atau 12,35 $>3,14$ maka tolak $\mathrm{H}_{0}$ dan terima $\mathrm{H}_{1}$, artinya terdapat pengaruh yang positif signifikan habits of mind dan kemandirian belajar secara bersama-sama terhadap kemampuan berpikir reflektif matematis.

Selanjutnya uji analisis regresi ganda $\mathrm{Y}$ atas $\mathrm{X}_{1}$, untuk kriteria pengujiannya,

$\mathrm{H}_{0}$ : regresi ganda $\mathrm{Y}$ atas $\mathrm{X}_{1}$ tidak signifikan

$\mathrm{H}_{1}$ : regresi ganda $\mathrm{Y}$ atas $\mathrm{X}_{1}$ signifikan 
Dari hasil data yang diperoleh, ternyata nilai $t_{\text {hitung }}<t_{\text {tabel}}$, yaitu: $0,69<1,99$, maka $\mathrm{H}_{1}$ diterima. Hal ini berarti tidak terdapat pengaruh yang signifikan habits of mind $\left(\mathrm{X}_{1}\right)$ terhadap kemampuan berpikir reflektif matematis $(\mathrm{Y})$.

Terakhir, uji analisis regresi ganda $\mathrm{Y}$ atas $\mathrm{X}_{2}$, untuk kriteria pengujiannya,

$\mathrm{H}_{0}$ : regresi ganda $\mathrm{Y}$ atas $\mathrm{X}_{2}$ tidak signifikan

$\mathrm{H}_{1}$ : regresi ganda $\mathrm{Y}$ atas $\mathrm{X}_{2}$ signifikan

Ternyata dari hasil yang diperoleh, nilai $t_{\text {hitung }}>t_{\text {tabel }}$, yaitu: 3,67 $>1,99$, maka $\mathrm{H}_{0}$ diterima. Hal ini berarti terdapat pengaruh yang signifikan kemandirian belajar $\left(\mathrm{X}_{2}\right)$ terhadap kemampuan berpikir reflektif matematis (Y).

\section{PEMBAHASAN}

Hasil penelitian yang sudah diuraikan kemudian dibahas merujuk pada penelitian-penelitian yang sudah dilakukan. Pembahasan ini dilakukan mengacu pada tujuan penelitian ataupun hipotesis penelitian. Mengacu pada penelitian Ramadhani, et. al. (2019), kemampuan berpikir reflektif tidak datang dengan sendirinya dan tidak didapat dalam waktu yang singkat hal ini memerlukan pembiasaan-pembiasaan sedini mungkin yang dilakukan dalam proses pembelajaran untuk memperoleh kemampuan berpikir reflektif. Pembiasaan-pembiasaan ini yang nantinya akan membentuk kemampuan berpikir siswa. Sehingga dalam memiliki kemampuan berpikir reflektif tidak hanya diperoleh dari kemampuan siswa dalam berpikir melainkan bisa didapat dari kebiasaan berpikir (habits of mind) siswa. Seperti pendapat Komala (2017) yang menyatakan bahwa selain kemampuan berpikir reflektif matematis, terdapat aspek lain yang juga memberikan pengaruh yang signifikan yaitu aspek psikologis. Hal ini tentunya dapat menjadi faktor pendukung peningkatan kemampuan berpikir reflektif matematis. Habits of mind yang dimiliki siswa akan membantu siswa untuk dapat menghubungkan suatu persoalan matematika.

Selain dari habits of mind, kemandirian belajar menjadi salah satu aspek psikologis yang diperlukan dalam peningkatan kemampuan berpikir reflektif. Kemandirian belajar yang dapat dilakukan siswa mendorong siswa untuk memiliki kebiasaan, salah satunya kebiasaan berpikir. Ketika siswa mandiri dalam belajar, tentu akan memiliki habits of mind. Dalam belajar, kebiasaan berpikir dan kemandirian belajar akan menjadikan siswa lebih mengusai setiap pelajaran yang baru, apalagi pelajaran yang pernah didapatnya. Siswa yang mandiri memiliki kebiasaan mempelajari materi baru dan belajar materi sudah pernah dipelajari, akan memicu caranya berpikir. Menurut Anwar, \& Sofiyan (2018), kemampuan berpikir reflektif tidaklah bergantung pada pada pengetahuan semata, akan tetapi sangat bergantung bagaimana siswa dalam memanfaatkan pengetahuan yang ada. Sehingga sikap siswa dalam menghadapi soal juga dapat dilihat dari habits of mind dan kemandirian belajar. Siswa yang memiliki habits of mind yang tinggi tentunya akan lebih mudah dalam menyelesaikan suatu persoalan matematika yang baru. Didukung dengan kemandirian belajar siswa yang tinggi, maka pada saat menyelesaikan persoalan, siswa tidak hanya berfokus pada persoalan yang baru saja diterima melainkan mampu menghubungkan dengan pengetahuan lamanya.

Habits of mind dan kemandirian belajar akan membentuk kemampuan siswa dalam berpikir, salah satunya kemampuan berpikir reflektif matematis. Dalam kemampuan berpikir reflektif yang perlu menghubungkan pengetahuan baru dengan pengetahuan lama tentunya akan sangat signifikan dengan habits of mind dan kemandirian belajar yang tinggi. Ketiga hal tersebut memiliki kerterkaitan dalam berhasilnya pembelajaran matematika. Habits of mind dan kemandirian belajar akan membuat siswa percaya diri dan berani dalam mengerjakan soal-soal matematika yang akan memunculkan kemampuan berpikir reflektif.

Berdasarkan hasil dari penelitian yang dilakukan habits of mind dan kemandirian belajar siswa secara bersama-sama terhadap kemampuan berpikir reflektif matematis perlu ditingkatkan lebih karena 
kemandirian belajar berperan dalam meningkatkan habits of mind sehingga siswa dapat menyelesaikan suatu persoalan baru dengan menghubungkan pengetahuan baru dan pengetahuan lama yang dimiliki.

Menurut Jaenudin, et. al. (2017) dengan memiliki kemampuan berpikir reflektif matematis tentu siswa akan mengetahui apa yang dibutuhkan dalam proses belajar. Kemampuan berpikir reflektif matematis mengaitkan pengetahuan baru dan pengetahuan lama sehingga siswa diharapkan memiliki habits of mind yang tinggi. Siswa yang memiliki habits of mind tinggi terhadap pelajaran matematika akan menganggap matematika pelajaran yang tidak sulit melainkan sebuah pelajaran yang menyenangkan. Selain itu siswa yang memiliki habits of mind matematika akan menentukan keberhasilannya dalam memahami matematika. Pada konteks lain, Menurut Nurmala, et. al. (2018) terdapat aspek psikologis yang turut memberikan kontribusi terhadap keberhasilan siswa dalam memahami matematika dengan baik yaitu habits of mind. Habits of mind yang dimiliki siswa akan meningkatkan kemampuan berpikir siswa. Siswa dalam menyelesaikan permasalahan matematika tidak akan kesulitan. Siswa yang memiliki habits of mind tinggi akan memiliki kesadaran dalam belajar.

Habits of mind menurut pandangan Dwirahayu, et. al. (2018) mengisyaratkan bahwa pembiasaan membutuhkan suatu kedisiplinan, pikiran yang dilatih sedemikian rupa, sehingga menjadi kebiasaan untuk terus berusaha melakukan tindakan yang lebih bijak dan cerdas. Dengan habits of mind yang dimiliki, siswa tidak hanya dapat menyelesaikan suatu persoalan tetapi dapat menyelesaikan dengan bijak dan cerdas. Segala proses yang dilakukan bisa berakibat dari hasil habits of mind. Habits of mind juga dapat mencerminkan kemampuan siswa dalam berpikir. Kebiasan yang terus menerus dilakukan tentu akan kuat dan berpengaruh terhadap tindakan yang dilakukan. Ketika siswa memiliki habits of mind yang tinggi dalam belajar matematika, tentu siswa tersebut tidak akan merasa matematika sebuah pelajaran sulit.

Setiap pembelajaran matematika, habits of mind tentunya sangat diperlukan. Matematika yang bersifat abstrak memerlukan habits of mind yang tinggi. Siswa yang memiliki kemampuan berpikir tinggi tentunya memiliki habits of mind yang tinggi juga. Kedua hal ini berkaitan dalam keberhasilan dalam belajar. Dengan adanya habits of mind, saat siswa dihadapkan suatu persoalan akan dengan baik dan benar dalam menjawabnya. Habits of mind menjadikan siswa lebih tekun, teliti, dan kehati-hatian dalam mengerjakan soal matematika.

Dengan habits of mind yang dimiliki siswa, akan timbul kemampuan berpikir reflektif matematis siswa, yaitu siswa mampu menghadapi persoalan dengan mengaitkan pengetahuan yang dimilikinya. Memiliki habits of mind juga menjadikan matematika bukan lagi sebuah pelajaran sulit dan menakutkan. Habis of mind menjadikan siswa lebih percaya diri dalam menyelesaikan persoalan matematika. Siswa yang memiliki habits of mind dan kemampuan berpikir reflektif matematis akan menjadikan matematika sebagai salah satu pendukung keberhasilan dan kesuksesan belajar.

Akan tetapi, dalam penelitian ini habits of mind berpengaruh secara tidak signifikan terhadap kemampuan berpikir reflektif matematis. Habits of mind perlu ditingkatkan dalam pembelajaran agar tujuan pembelajaran khususnya matematika menjadi lebih baik untuk tercapainya kemampuan berpikir reflektif matematis sehingga siswa dapat menyelesaikan permasalahan matematika yang diberikan.

Dalam tinjauan penelitian Egok (2016), dari persamaan regesi kemandirian belajar terhadap hasil belajar matematika terlihat bahwa pengaruhnya searah (positif). Siswa yang memiliki kemandirian belajar tinggi akan signifikan dengan kemampuannya dalam berpikir sehingga memaksimalkan hasil belajarnya. Sehingga hasil belajar dapat dilihat dari kemampuan berpikir siswa. Kemampuan berpikir reflektif menjadi salah satu kemampuan yang diperlukan untuk mendapatkan hasil belajar yang maksimal. Seperti pendapat Suhartina, et. al. (2019), kemampuan berpikir reflektif matematis, perlu juga diperhatikan salah satu aspek afektif yaitu kemandirian belajar (self-regulated). Siswa yang memiliki kemampuan berpikir reflektif matematis akan dapat menyelesaikan masalah matematika dengan mengaitkan pengetahuan baru dengan 
pengetahuan lamanya karena memiliki kemandirian dalam belajar. Sehingga siswa yang mandiri dalam belajar tentu akan berhasil dalam menyelesaikan persoalan matematika.

Menurut Komala (2017), kemandirian belajar berkaitan erat dengan hasil belajar matematika siswa dalam hal ini kemampuan berpikir reflektif matematis siswa. Kemandirian belajar merupakan salah satu faktor yang mempengaruhi hasil belajar matematika siswa yang berasal dari dalam diri siswa. Kontribusi kemandirian belajar dalam kemampuan siswa dalam menyelesaikan persoalan matematika menjadi sangat penting. Siswa yang mandiri tidak akan bergantung pada orang lain dalam menyelesaikan masalah yang dihadapi. Momok matematika yang sulit dan menakutkan akan hilang jika siswa mandiri dalam belajar. Siswa yang mandiri tentunya siap menerima pelajaran atau persoalan matematika yang baru. Karena dalam belajar tidak hanya mengandalkan kemampuan berpikir saja, namun juga diperlukan kemandirian. Sikap mandiri membuat siswa menemukan hal-hal baru dalam belajar. Kemandirian belajar siswa juga membuat siswa lebih bersemangat dalam belajar, serta memicu peningkatan kemampuan berpikir siswa.

Pembelajaran matematika yang tidak didukung oleh kemandirian belajar, siswa cenderung akan kesulitan dalam mengerjakan soal-soal matematika. Siswa yang tidak mandiri tidak akan siap jika diberikan materi ataupun diminta untuk mengerjakan kuis. Tidak kesiapan siswa ini dapat mengakibatkan siswa menjadi lemah dalam penyelesaikan masalah yang dihadapinya. Namun, siswa yang memiliki kemandirian dan kemampuan reflektif tidak akan kesulitan dalam pembelajaran matematika. Karena kemandirian yang tinggi dan kemampuan berpikir reflektif matematis yang signifikan akan mendorong siswa dalam menyelesaikan soal-soal matematika dengan baik dan benar.

\section{SIMPULAN}

Berdasarkan hasil pengujian hipotesis dan pembahasan hasil penelitian yang sudah dikemukakan, maka peneliti dapat disimpulkan, 1) terdapat pengaruh yang positif dan signifikan habits of mind dan kemandirian belajar secara bersama-sama terhadap kemampuan berpikir reflektif matematis, dibuktikan dengan nilai nilai $F_{\text {hitung }}=12,79>F_{\text {tabel }}=3,12 ; 2$ ) terdapat pengaruh yang positif dan tidak signifikan habits of mind terhadap kemampuan berpikir reflektif matematis, dibuktikan dengan nilai $t_{\text {hitung }}=0,69<\mathrm{t}_{\text {tabel }}=$ $1,99 ; 3)$ terdapat pengaruh yang positif dan signifikan kemandirian belajar terhadap kemampuan berpikir reflektif matematis, dibuktikan dengan nilai $t_{\text {hitung }}=3,67>t_{\text {tabel }}=1,99$.

\section{DAFTAR RUJUKAN}

Anwar, \& Sofiyan. (2018). Teoritik Tentang Berpikir Reflektif Siswa Dalam Pengajuan Masalah Matematis. Numeracy, 5(1), 91-101. https://doi.org/https://doi.org/10.46244/numeracy.v5i1.330

Awalia, I., Pamungkas, A. S., \& Alamsyah, T. P. (2019). Pengembangan Media Pembelajaran Animasi Powtoon pada Mata Pelajaran Matematika di Kelas IV SD. Kreano, Jurnal Matematika KreatifInovatif, 10(1), 49-56. https://doi.org/10.15294/kreano.v10i1.18534

Dwirahayu, G., Kustiawati, D., \& Bidari, I. (2018). Pengaruh Habits of Mind. JPPM (Jurnal Penelitian Dan Pembelajaran Matematika), 11(2), 1-13. https://doi.org/http://dx.doi.org/10.30870/jppm.v11i2.3757

Edo, S. I. (2018). Jenis Kekeliruan Akibat Menghafal Prosedur Rutin Dalam Melakukan Operasi Penjumlahan Dan Pengurangan Bilangan Pecahan. Mosharafa: Jurnal Pendidikan Matematika, 5(3), 223-232. https://doi.org/10.31980/mosharafa.v5i3.278

Egok, A. S. (2016). KEMAMPUAN BERPIKIR KRITIS DAN KEMANDIRIAN BELAJAR DENGAN HASIL BELAJAR MATEMATIKA. Jurnal Pendidikan Dasar, 7(2), 186-199. https://doi.org/https://doi.org/10.21009/JPD.072.01

Ghifari, M., Salsabila, E., \& Aziz, T. A. (2021). Analisis Kemampuan Berpikir Reflektif Matematis pada 
Bentuk Aljabar Ditinjau Perbedaan Gender. JKPM (Jurnal Kajian Pendidikan Matematika), 6(2), 243. https://doi.org/10.30998/jkpm.v6i2.9542

Handayani, A. D. (2015). Mathematical Habits of Mind : Urgensi dan Penerapannya dalam Pembelajaran $\begin{array}{lllll}\text { Matematika. Jurnal } & \text { Math } & \text { Educator } & \text { Nusantara, } & \text { 1(2), }\end{array}$ https://ojs.unpkediri.ac.id/index.php/matematika/article/view/240

Harahap, R., Dewi, I., \& Sumarno. (2012). Perbedaan Peningkatan Kemampuan Komunikasi dan Koneksi Matematis Siswa Melalui Pembelajaran Kontekstual dengan Kooperatif Tipe STAD di SMP AlWashliyah 8 Medan. Paradikma: Jurnal Pendidikan Matematika, 5(2), 186-204.

Jaenudin, J., Nindiasari, H., \& Pamungkas, A. S. (2017). Analisis Kemampuan Berpikir Reflektif Matematis Siswa Ditinjau Dari Gaya Belajar. Prima: Jurnal Pendidikan Matematika, 1(1), 69. https://doi.org/10.31000/prima.v1i1.256

Komala, E. (2017). Penerapan Resource Based Learning Untuk Meningkatkan Kemampuan Berpikir Reflektif Matematis Dan Kemandirian Belajar Siswa. SOSIOHUMANIORA: Jurnal Ilmiah Ilmu Sosial Dan Humaniora, 3(2), 137-144. https://doi.org/10.30738/sosio.v3i2.1612

Krissandi, A. D. S., \& Setiawan, K. A. C. (2018). Perubahan Kurikulum dan Pendidikan Profesi Guru: Upaya Menemukan Arah Pendidikan yang Ideal atau Konstelasi Kekuasaan? SAP (Susunan Artikel Pendidikan), 3(2), 93-102. https://doi.org/10.30998/sap.v3i2.3027

Mulyatna, F., Imswatama, A., \& Rahmawati, N. D. (2021). Design Ethnic-Math HOTS: Mathematics Higher Order Thinking Skill Questions Based On Culture and Local Wisdom. Malikussaleh Journal of Mathematics Learning (MJML), 4(1), 48. https://doi.org/10.29103/mjml.v4i1.3059

Muntazhimah, M. (2019). Pengembangan Instrumen Kemampuan Berpikir Reflektif Matematis siswa Kelas 8 SMP. Imajiner: Jurnal Matematika Dan Pendidikan Matematika, 1(5), 237-242. https://doi.org/10.26877/imajiner.v1i5.4551

Nindiasari, H., Novaliyosi, \& Subhan, A. (2016). Desain Didaktis Tahapan Kemampuan dan Disposisi Berpikir Reflektif Matematis Berdasarkan Gaya Belajar. JURNAL KEPENDIDIKAN, 46(2), 219-232. https://doi.org/https://doi.org/10.21831/jk.v46i2.10681

Nurmala, N., Rohaeti, E. E., \& Sariningsih, R. (2018). Pengaruh Habits of Mind (Kebiasaan Berpikir) Terhadap Pemecahan Masalah Matematik Siswa Smp. Journal on Education, 1(2), 163-168. https://doi.org/https://doi.org/10.31004/joe.v1i2.41

Prastowo, A. (2014). Pemenuhan Kebutuhan Psikologis Peserta Didik Sd/Mi Melalui Pembelajaran Tematik-Terpadu. JURNAL JPSD (Jurnal Pendidikan Sekolah Dasar), 1(1), 1. https://doi.org/10.26555/jpsd.v1i1.a538

Ramadhani, S. S., Hartin, S., \& Lestari, W. D. (2019). Pengaruh penggunaan model pembelajaran pair check terhadap kemampuan berpikir reflektif siswa ditinjau dari tingkat kebiasaan berpikir. PROXIMAL: Jurnal Penelitian Matematika Dan Pendidikan Matematika, 2(2), 1-10. https://ejournal.my.id/proximal/article/view/219

Sudjatmiko, T. (2019). Siswa Harus Pahami Pentingnya Kemandirian (Online), (https://www.krjogja.com/peristiwa/nasional/siswa-harus-pahami-pentingnya-kemandirian/) diakses 21 Juni 2021.

Suhartina, R., Farhan, M. S., Kushendri, \& Nurjaman, A. (2019). Analisis kemampuan berpikir reflektif siswa SMP di Kota Cimahi pada materi operasi aljabar ditinjau dari self regulated. Journal on Education, 1(3), 203-210. https://doi.org/https://doi.org/10.31004/joe.v1i3.138

Utarni, H., \& Mulyatna, F. (2020). Penerapan Pembelajaran Realistic Mathematics Education dengan Strategi Means Ends Analysis untuk Meningkatkan Kemampuan Berpikir Kritis. ARITHMETIC: Academic Journal of Math, 02(01), 15-34. https://doi.org/http://dx.doi.org/10.29240/ja.v2i1.1399 